\title{
Involvement of apoptotic pathways in docosahexaenoic acid-induced benefit in prostate cancer: Pathway-focused gene expression analysis using $\mathrm{RT}^{2}$ Profile $\mathrm{PCR}$ Array System
}

Yanan Sun ${ }^{1 \dagger}$, Xiaopeng $\mathrm{Jia}^{2^{*+}}$, Lianguo $\mathrm{Hou}^{3}$, Xing Liu ${ }^{4}$ and Qiang Gao ${ }^{5}$

\begin{abstract}
Background: Present study aimed to better understand the potential apoptotic pathways that involved in docosahexaenoic acid (DHA)-induced apoptosis of prostate cancer cells.

Methods: Human prostate cancer DU145 cells were treated with different concentrations of fish oil, omega-3 PUFA (DHA, and Eicosapentaenoic acid, EPA), or omega-6 PUFA (Arachidonic acid, AA). Cell viability and apoptosis were evaluated by MTT assay and Hoechst staining. Pathway-focused gene expression profiling of DU145 cells was analyzed with the $\mathrm{RT}^{2}$ Profile PCR Array System. The results were verified by real time quantitative polymerase chain reaction ( $R T-q P C R)$.

Results: AA exposure showed no obvious effect on viability of DU145 cells. However, exposure with fish oil, EPA, or DHA for $24 \mathrm{~h}$ significantly affected cell viability. The growth inhibition of DHA was more pronounced than that of EPA and showed a time-dependent increase. DHA exposure caused typical apoptotic characteristics. Ten genes were more expressed, while 5 genes were less expressed following DHA exposure. RT-qPCR confirmed the time dependent effect of DHA on the expression of these differentially expressed genes. KEGG pathway analysis showed that DHA may induce the apoptosis of cancer cells preferentially through mediating P53, MAPK, TNF, PI3K AKT, and NF-kB signaling pathways.

Conclusion: Our study demonstrated the beneficial action of DHA on human prostate carcinoma cell line DU145. The pro-apoptotic effect of DHA on DU145 cells may involve mediation various pathways, especially P53, MAPK, TNF, PI3K AKT, and NF-KB signaling pathways. Molecular mechanisms of DHA on apoptosis of cancer cells still need to be further clarified.
\end{abstract}

Keywords: Human prostate carcinoma cell, DU145 cells, Docosahexaenoic acid (DHA), RT ${ }^{2}$ profile PCR array system

* Correspondence: xiaopengjia71@163.com

${ }^{\dagger}$ Equal contributors

2Department of Urology, The Third Hospital of Hebei Medical University,

Shijiazhuang 050051, China

Full list of author information is available at the end of the article

(c) The Author(s). 2017 Open Access This article is distributed under the terms of the Creative Commons Attribution 4.0 International License (http://creativecommons.org/licenses/by/4.0/), which permits unrestricted use, distribution, and reproduction in any medium, provided you give appropriate credit to the original author(s) and the source, provide a link to the Creative Commons license, and indicate if changes were made. The Creative Commons Public Domain Dedication waiver (http://creativecommons.org/publicdomain/zero/1.0/) applies to the data made available in this article, unless otherwise stated. 


\section{Background}

Prostate cancer is one of the most commonly diagnosed cancers in elderly men, with approximately one million new cases diagnosed per year worldwide [1]. The incidence of prostate cancer in Asian populations has long been established to be lower than that in Western populations. However, the prevalence of the disease has shown a rapid increase in Asian countries, including China [2, 3]. More and more cases of prostate cancer have been diagnosed in China in recent years [4]. In Shanghai alone, the incidence of prostate cancer has increased from 1.6 to 7.7 per 10,000 person (4.8 folds) during 1973 to 2000 [5]. One explanation for this rapid change is the westernization of dietary life style [6]. Compared to Eastern counterpart, the diet of Western population is generally characterized by higher levels of saturated fats that may contribute to the development of prostate cancer [7]. Daily intake of the individual fatty acids such as omega-3 polyunsaturated fatty acids (PUFA) has been reported to be comparatively low in most Westernized countries [8]. Dietary factors, including the consumption of unsaturated fat, may reduce the risk or progression of prostate cancer [9].

Certain omega-3 PUFA, including docosahexaenoic acid (DHA), have been well recognized to exert beneficial effects in prevention of a series of chronic diseases, including cancer [10]. Dietary fat fish, fish oils and their active omega-3 PUFAs constituents have been associated with the reduced risk of prostate cancer $[8,11,12]$. Various pathways have been reported to involve in the antiproliferative effects of omega-3 PUFAs in prostate cancer [13-15]. It has been suggested that omega-3 PUFAs may inhibit the incidence and development of prostate cancer through various mechanisms $[16,17]$. The regulation of the apoptotic pathways is one of the potential mechanisms that responsible for the beneficial effects of dietary omega-3 PUFA [18]. The increased apoptosis was observed following the treatment with a fish oil diet or DHA, with the possible induction of both the intrinsic and extrinsic apoptotic pathways [19]. The pro-apoptotic effect of DHA has been reported to involve modifications of the expression and activity of different intracellular apoptotic pathways [20, 21]. Therefore, to better understand the potential apoptotic pathways involved in DHA-induced apoptosis of prostate cancer cells, pathway-focused gene expression analysis was performed in our study using $\mathrm{RT}^{2}$ Profile PCR Arrays.

\section{Methods}

\section{Cell culture and treatment}

The human prostate carcinoma cell line DU145 was purchased from the Shanghai cell bank of Chinese Academy of Sciences (Shanghai, China). DU145 cells were cultured in Dulbecco's modified eagle medium
(DMEM, Gibico, Carlsbad, CA, USA) supplemented with $10 \%$ fetal bovine serum (FBS, Hangzhou Sijiqing Company, China), $100 \mathrm{U} / \mathrm{mL}$ penicillin and $0.1 \mathrm{mg} / \mathrm{mL}$ streptomycin. Cells were incubated in a $5 \% \mathrm{CO}_{2}$ incubator (Sanyo Electric Biomedical CO., LTD., Japan) at $37^{\circ}$ C. The media were refreshed every 2-3 days. Fish oil (Shanghai Haling biotechnology Co., Ltd., Shanghai, China), DHA, eicosapentaenoic acid (EPA), and arachidonic acid (AA, $50 \mathrm{mmol} / \mathrm{L}$, Sigma) were prepared using $\mathrm{NaOH}$ and were dissolved in BSA (0.01 mol/L PBS, 1:9). Media with and without BSA were used as BSA and blank controls.

\section{MTT assay}

Cell viability was measured using an MTT kit (Sigma). DU145 cells $\left(200 \mu \mathrm{L}, 2 \times 10^{4} / \mathrm{mL}\right)$ were seeded in 96well plates and synchronized by serum starvation in DMEM containing 1\% FBS for $24 \mathrm{~h}$. The cells were then incubated with fish oil at a final concentration of 50, 150, 250, and $500 \mu \mathrm{mol} / \mathrm{L}$, or with AA, EPA, and DHA at a final concentration of $10,25,50$, and $100 \mu \mathrm{mol} / \mathrm{L}$ for $24 \mathrm{~h}$, respectively. Control cells were treated with BSA (BSA group) or without any treatment (Blank control). MTT (5 mg/mL, $20 \mu \mathrm{L})$ was added to each well and incubated for $4 \mathrm{~h}$. The supernatants were removed and dimethyl sulfoxide (150 $\mu \mathrm{L}$, Sigma) was added. The absorbance was measured at $490 \mathrm{~nm}$ using a DH5031 enzyme-linked immunometric meter (Nanjing Medical Instrument Factory, China).

\section{Hoechst staining}

Cell apoptosis was determined by Hoechst staining. DU145 cells $\left(8 \times 10^{4}\right)$ were plated in a 24 -well plate and incubated with DHA for $24 \mathrm{~h}$. Cells were then fixed with acetone for $30 \mathrm{~min}$, followed by staining with Hoechst 33258 (Beyotime Institute of Biotechnology, Jiangsu, China) for $15 \mathrm{~min}$. Apoptosis of cells was assayed under a fluorescent microscope (Olympus, Tokyo, Japan).

\section{RT2 Profile PCR Arrays}

DU145 cells treated with DHA were then underwent pathway-focused gene expression analyses. Total RNA was extracted with Trizol and was quantified by NanoDrop ND-1000 Spectrophotometer (NanoDrop Technologies). First-strand cDNA was synthesized using a $\mathrm{RT}^{2}$ first-strand kit (SABiosciences, Frederick, MD, USA) according to the manufacturer's instructions. Pathway-focused gene expression analyses were performed using RT2 Profile PCR Arrays (PAHS-012Z, Qiagen, USA). The expressions of 84 key genes involved in apoptosis-related pathways were measured. 
Real time quantitative polymerase chain reaction (RT-qPCR) To validate the effect of DHA on expression of genes that mediating the activity of apoptosis-related pathways, RT-qPCR analysis was further performed. After treatment of DU145 cells with different concentrations of DHA for $24 \mathrm{~h}$, total RNA was extracted and reverse transcribed to cDNA. RT-qPCR was conducted using a SYBR Green quantitative RT-PCR kit (Invitrogen, Carlsbad, California). PCR program was $50{ }^{\circ} \mathrm{C}$ and $95{ }^{\circ} \mathrm{C}$ each for 2 min followed by 40 cycles at $95{ }^{\circ} \mathrm{C}$ for $15 \mathrm{~s}$ and $52{ }^{\circ} \mathrm{C}$ for $30 \mathrm{~s}$. The primers used are summarized in Table 1 . Data were analyzed by $2^{-\Delta \Delta C t}$ method using TBP as a reference gene.

\section{Statistical analysis}

Data were expressed as mean \pm standard deviation (SD). Statistical significance was analyzed using ANOVA followed by least significant difference test or $t$ test. All statistical analysis was performed with SPSS, version17.0 (SPSS Inc., Chicago, IL, USA). A p value of less than 0.05 was considered as statistically significant.

\section{Results}

Effect of fish oil, AA, EPA, or DHA on DU145 cell viability The viability of DU145 cells was determined by MTT assay. As shown in Fig. 1a, after exposure with different concentrations of fish oil for $24 \mathrm{~h}$, viability of DU145 cells was significantly affected and showed a dosedependent decrease. Therefore, the effect of dose dependent effect of AA, EPA, or DHA on viability of DU145 cells was further investigated. AA exposure showed no obvious effect on viability of DU145 cells (Fig. 1b). By contrast, exposure of DU145 cells to EPA and DHA significantly inhibited cell viability in a dose dependent manner (Fig. 1c and d). The growth inhibition of DHA was more pronounced than that of EPA. Therefore, DHA was used in the following study. Time dependent effect of DHA exposure on the viability of DU145 cells was further evaluated with $50 \mu \mathrm{mol} / \mathrm{L}$ DHA. As shown in Fig. 1e, growth inhibition-induced by DHA was enhanced with the increased time.

\section{Effect of DHA on DU145 cell apoptosis}

Apoptosis of DU145 cells was evaluated following the exposure of cells with DHA $(50 \mu \mathrm{mol} / \mathrm{L})$ for $24 \mathrm{~h}$. Morphological analysis using Hoechst 33258 stain showed typical apoptotic characteristics of condensation and segmentation of the nucleus after DHA exposure (Fig. 2).

\section{Effect of DHA on apoptosis pathway-focused gene ex- pression profiling}

To gain insight of genes involving in DHA-induced apoptosis, pathway-focused gene expression profiling of DU145 cells was analyzed with the $\mathrm{RT}^{2}$ Profile PCR
Table 1 Primes used for RT-qPCR

\begin{tabular}{|c|c|c|}
\hline Gene & Prime & Length (bp) \\
\hline \multirow[t]{2}{*}{ Caspase 3} & Sense: 5'-TCTGGTTTCGGTGGGTGT-3' & 287 \\
\hline & Antisense:5'-TGAGGTTTGCTGCATCGACAT-3' & \\
\hline \multirow[t]{2}{*}{ Caspase 1} & Sense: 5'-ACATCCCACAATGGGCTCTG-3' & 233 \\
\hline & Antisense:5'-TTCACTTCCTGCCCACAGAC-3' & \\
\hline \multirow[t]{2}{*}{ Caspase 9} & Sense: 5'-CAGGCCCCATATGATCGAGG-3' & 194 \\
\hline & Antisense:5'-TCGACAACTTTGCTGCTTGC-3' & \\
\hline \multirow[t]{2}{*}{ Caspase 12} & Sense: 5'-ATCCAACGGTGTTCTGGTCC-3' & 360 \\
\hline & Antisense:5'-TCTCGCATCCCCAAAAGGTC-3' & \\
\hline \multirow[t]{2}{*}{ TNF } & Sense: 5'-CTGGGCAGGTCTACTTTGGG-3' & 272 \\
\hline & Antisense:5'-CTGGAGGCCCCAGTTTGAAT-3' & \\
\hline \multirow[t]{2}{*}{ TP53 } & Sense: 5'-ACCTATGGAAACTACTTCCTGAAA-3' & 500 \\
\hline & Antisense:5'-ACCATCGCTATCTGAGCAGC-3' & \\
\hline \multirow[t]{2}{*}{$\mathrm{BCL} 2$} & Sense: 5'-TTTGTGGAACTGTACGGCCC-3' & 451 \\
\hline & Antisense: 5'-CGGTGCTTGGCAATTAGTGG-3' & \\
\hline \multirow[t]{2}{*}{ CIDEA } & Sense: 5'-GTGCAGGCAGACAGACCTCC-3' & 487 \\
\hline & Antisense: 5'-CTTCACGTTAAGGCAGCCGA-3' & \\
\hline \multirow[t]{2}{*}{ DFFA } & Sense: 5'-TACGTCAGAGTTGTGCCACC-3' & 312 \\
\hline & Antisense:5'-TGGTAACCAACTCCAAATCCTGA-3' & \\
\hline \multirow[t]{2}{*}{ AlFM1 } & Sense: 5'-GTTCCAGCGATGGCATGTTC-3' & 230 \\
\hline & Antisense: 5'-ACGCGGCCTTTTCTGTTTC-3' & \\
\hline \multirow[t]{2}{*}{ AKT1 } & Sense: 5'-CAGGAGGTTTTTGGGCTTGC-3' & 418 \\
\hline & Antisense: 5'-TGTACTCCCCTCGTTGTGC-3' & \\
\hline \multirow[t]{2}{*}{ BID } & Sense: 5'-CATAAGGAGGAAGCGGGTAGTC-3' & 174 \\
\hline & Antisense: 5'-ACCGTTGTTGACCTCACAGT-3' & \\
\hline \multirow[t]{2}{*}{ AKT1 } & Sense: 5'-CAGCCTCCCTCCGAGTTTG-3' & 446 \\
\hline & Antisense: 5'-ACCTGGTTTAGCACTGAGCG-3' & \\
\hline \multirow[t]{2}{*}{ XIAP } & Sense: 5'-ATTTCCAGATTGGGGCTCGG-3' & 449 \\
\hline & Antisense:5'-TTGGTAGACTGCGTGGCACT-3' & \\
\hline \multirow[t]{2}{*}{ TBP } & Sense: 5'-CAGGGGTTCAGTGAGGTCG-3' & 107 \\
\hline & Antisense: 5'-ACCCTGGGTCACTGCAAAG-3' & \\
\hline
\end{tabular}

Array System. The differentially expressed genes were identified by fold changes greater than 2-folds. DU145 cells exposed to DHA showed an obviously different gene expression pattern when compared with the control (Additional file 1: Table S1). Ten genes were identified to be upregulated greater than 2-folds after DHA exposure, including three apoptosis-related cysteine peptidases, caspase 1, 3 and 9, pro-apoptotic protein BAX, cell death-inducing factors CIDEA and DFFA, tumor necrosis related factors TNFRSF1A, LTA and TNF, tumor suppressor gene TP53 (Table 2). Meanwhile, 5 genes were found to be downregulated at least 2-folds, they were X-linked apoptosis inhibitor protein XIAP, mitochondrion-associated apoptosis inducing factor AIFM1, protein kinase AKT1, BH3-containing proteins BID and BIRC6. To confirm the findings of our 

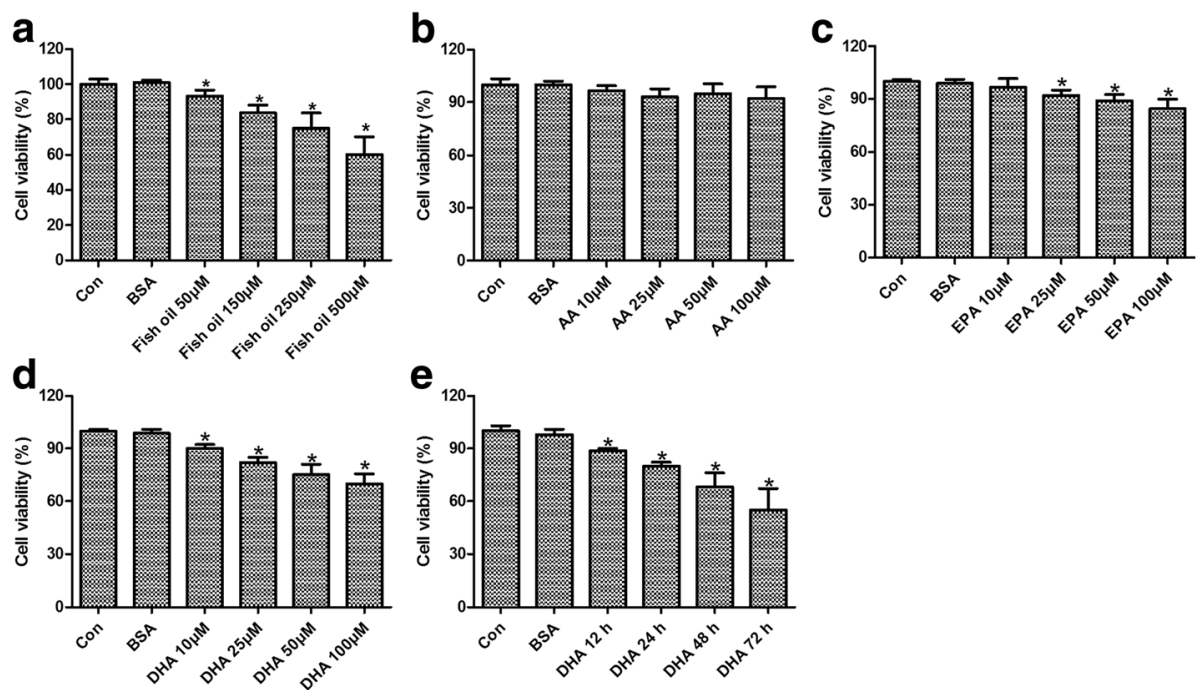

Fig. 1 Viability of human prostate cancer DU145 cells as determined by MTT assay. The dose dependent effect of fish oil (a), AA (b), EPA (c), and DHA (d) on viability of DU145 cells. The time-dependent effect of DHA on cell viability (e). ${ }^{*} p<0.05$ vs the control groups

pathway-focused gene expression analysis, the timedependent effect of DHA on some of the differentially expressed genes were further assessed by RT-qPCR. As shown in Fig. 3, DHA treatment for 24 h significantly upregulated the expressions of caspase 1, 3 and 9, BAX, CIDEA, DFFA, TNF and TP53, while downregulated the expressions of XIAP, AIFM1, AKT1, BID and BIRC6 $(p<0.05)$. DHA treatment of DU145 cells showed a time dependent effect on the expressions of Caspase 3 and 9, BAX, CIDEA, TNF, XIAP, AIFM1 and BID $(p<0.05)$. These up- and down-regulated genes were further subjected to KEGG pathway analyses. KEGG pathway annotation showed that the targeted genes were highly enriched in several pathways, mainly involved in the P53 signaling pathway, MAPK signaling pathway, TNF signaling pathway, PI3K/AKT signaling pathway, and NF-kB signaling pathway (Table 3).

\section{Discussion}

Dietary fat consumption is a critical risk factor for development and progression of prostate cancer $[8,22]$. Omega-3 PUFA, particularly DHA, have shown important inverse associations with tumorigenesis and progression, with the inhibited cell proliferation and reduced incidence and progression of the tumors [23, 24]. Alteration in apoptosis may play a crucial role in this procedure $[20,25,26]$. However, the potential mechanisms have not been fully elucidated [27]. The critical analysis of PUFA action on potential apoptotic pathways have been carried out in this study. The findings of our study showed that DHA may modulate the apoptosis of prostate cells through different pathways. DHA exposure upregulated the gene expressions of Caspase 9, Caspase 3, DFFA, TP53, BAX, CIDEA, TNF, TNFRSF1A, Caspase 1, and LTA, while downregualted XIAP, AIFM1, BIRC6,
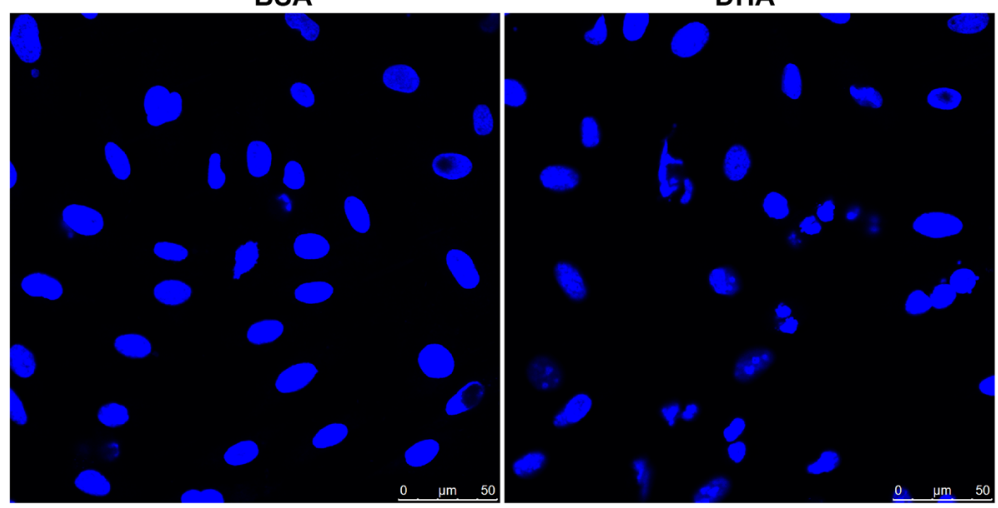

Fig. 2 Effect of DHA exposure on apoptosis of DU145 cells assessed by Hoechst 33258 staining 
Table 2 Effect of DHA on apoptosis pathway-focused gene expression profiling of DU145 cells

\begin{tabular}{|c|c|c|c|}
\hline Refseq & Symbol & Description & Folds \\
\hline NM_001229 & CASPASE 9 & Caspase 9, apoptosis-related cysteine peptidase & 12.10 \\
\hline NM_004346 & CASPASE 3 & Caspase 3, apoptosis-related cysteine peptidase & 4.88 \\
\hline NM_004401 & DFFA & DNA fragmentation factor, $45 \mathrm{kDa}$, alpha polypeptide & 3.21 \\
\hline NM_000546 & TP53 & Tumor protein p53 & 2.97 \\
\hline NM_004324 & BAX & BCL2-associated $\mathrm{X}$ protein & 2. \\
\hline NM_001279 & CIDEA & Cell death-inducing DFFA-like effector a & 2.3 \\
\hline NM_000594 & TNF & Tumor necrosis factor & 2. \\
\hline NM_001065 & TNFRSF1A & Tumor necrosis factor receptor superfamily, member $1 \mathrm{~A}$ & 2.12 \\
\hline NM_033292 & CASPASE 1 & Caspase 1, apoptosis-related cysteine peptidase & 2 \\
\hline NM_000595 & LTA & Lymphotoxin alpha (TNF superfamily, member 1) & \\
\hline NM_001167 & XIAP & X-linked inhibitor of apoptosis & 0.49 \\
\hline NM_004208 & AlFM1 & Apoptosis-inducing factor, mitochondrion-associated, 1 & 0 \\
\hline NM_016252 & BIRC6 & Baculoviral IAP repeat containing 6 & 0.32 \\
\hline NM_005163 & AKT1 & V-akt murine thymoma viral oncogene homolog 1 & \\
\hline NM_001196 & $\mathrm{BID}$ & $\mathrm{BH} 3$ interacting domain death agonist & \\
\hline
\end{tabular}

AKT1, and BID expressions. KEGG pathway annotation showed that DHA exposure mainly involved in the p53 pathway, TNF signaling pathway, AKT-related signaling pathway, and mitochondrial-related pathway, suggesting the modulation of the both extrinsic and intrinsic apoptotic pathways by DHA. Some of such pathways have been reported in DHA-induced pro-apoptosis of cancer cells [14, 28-30].

Previous studies indicated that increased dietary intakes of omega-6 PUFA like AA may worsen the development of prostate cancer. By contrast, intakes of omega-3 PUFA, such as EPA and DHA, may improve the development of prostate cancer [12]. A high dietary ratio of $n-6 / n-3$ fatty acids has been reported to increase the risk of prostate cancer [7]. In our study, AA exposure caused no obvious inhibition of proliferation of DU145 cells. This was quietly different from the results reported by Meng et al., which indicated that AA supplementation $(25,50,75,100,125,150,175 \mu \mathrm{mol} / \mathrm{L})$ resulted in significantly decreased viability of human prostate cancer PC-3 cells [22]. This conflicting result may be partially explained by the different concentration gradients and prostate cell lines used. However, exposure of DU145 cells to the EPA or DHA in our study markedly reduced the cell viability, and this effect showed a dose-dependent pattern. The more pronounced growth inhibition of DHA was observed. Similar results have been reported, which indicated that DHA was a tumor reducing omega-3 PUFA for both androgen-dependent and -independent prostate cancer cell lines ( $\mathrm{LNCaP}$ cells PC-3 cells) [22, 31, 32]. However, the study by Chung et al. indicated that DHA treatment showed litter response in androgen-dependent prostate cancer LNCaP cells
[33]. Schley et al. have reported that DHA was more potent in growth inhibition of human breast cancer MDAMB-231 cells than that of EPA [24]. While Liu and colleagues showed more efficacious growth inhibition of EPA than that of DHA [13]. The possible explanations for this disparity could be the different doses and cell lines used in these studies. Despite of these conflicting results, our results did show a pronounced growth inhibitory effect of omega-3 PUFA, EPA and DHA, on androgen-independent, hormone refractory prostate cancer DU145 cells. DHA exposure caused a timedependent growth inhibition on DU145 cells. Furthermore, apoptosis of DU145 cells was also found to be significantly enhanced following DHA treatment. All these results showed evidence suggested that omega-3 PUFA, particularly DHA, may exert beneficial effect on prostate cancer through inhibiting proliferation and promoting apoptosis of cancer cells.

The anticancer activity of omega 3-PUFA (DHA) has been suggested to be due to apoptosis induction of fatty acid [25, 34-36]. Different apoptotic pathways have been reported to involve in the anticancer actions of omega-3 fatty acids (DHA). The p53-mediated signaling pathways have been identified to involve in DHA-induced apoptosis and autophagy in cancer cells harboring wild-type p53 [28]. In prostate cancer cells harboring mutant p53, however, mitochondrial ROS-mediated Akt-mTOR signaling was found to induce apoptosis and autophagy [29]. DHA has also been shown to induce apoptosis through inhibiting the Akt/NF-kB pathway and by modulating the PI3K/AKT/p38 MAPK pathway [14, 24, 37, 38]. The suppression of genes involved in PDK1/Akt/Bad signaling and NF-kB pathways has also been suggested to 

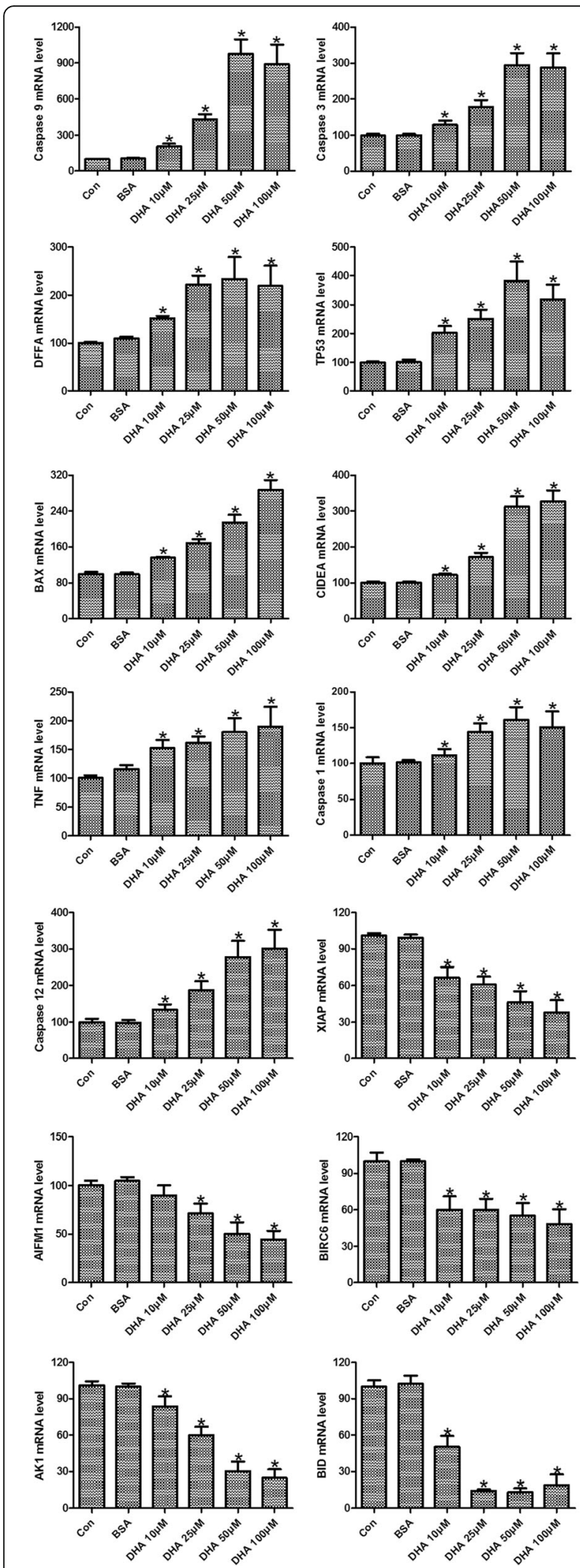

Fig. 3 RT-qPCR analysis of the time-dependent effect of DHA exposure on differentially expressed genes identified by pathway-focused gene expression analysis. ${ }^{*} p<0.05$ vs the BSA group
Table 3 Pathway enrich of apoptotic genes

\begin{tabular}{lll}
\hline Components & Gene count & Representative genes \\
\hline P53 signaling pathway & 6 & $\begin{array}{l}\text { Caspase 3, Caspase 9, TP53, } \\
\text { Bax, AKT1, BID }\end{array}$ \\
MAPK signaling pathway & 5 & $\begin{array}{l}\text { Caspase 3, TP53, TNF, } \\
\text { TNFRSF1A, AKT1 }\end{array}$ \\
TNF signaling pathway & 4 & Caspase 3, TNF, XIAP, AKT1 \\
PI3KAKT signaling pathway & 2 & Caspase 9, TP53 \\
NF-KB signaling pathway & 2 & TNF, XIAP \\
\hline
\end{tabular}

contribute to DHA-induced apoptosis [30, 39]. However, the pro-apoptotic molecular mechanisms of DHA have not been well established. Therefore, in the present study, the apoptosis-related genes that abnormally expressed in DHA-treated prostate cancer DU145 cells were screened using the specifically designed $\mathrm{RT}^{2}$ Profile PCR arrays. Among the 84 key genes involved in mediating apoptosisrelated pathways, 10 genes were more expressed in DHAexposed DU145 cells than control, while 5 genes were less expressed following DHA exposure (more than two-fold change). To confirm the accuracy of the present results, RT-qPCR was performed to validate some of the differently expressed genes in a time-dependent manner. The results showed that the expressions of these differently expressed genes were consistent with the data from microarray. KEGG pathway analysis of our study showed that DHA exposure may induce the apoptosis of cancer cells preferentially through mediating P53, MAPK, TNF, PI3K/AKT, and NF- $\mathrm{kB}$ signaling pathways, partially corroborating the results of previous studies. However, future studies are still needed to further clarify the molecular mechanisms of DHA-induced proapoptosis of cancer cells.

\section{Conclusions}

In conclusion, our study demonstrated the beneficial action of DHA on human prostate carcinoma cell line DU145. The pro-apoptotic effect of DHA on DU145 cells may involve mediating P53 signaling pathway, MAPK signaling pathway, TNF signaling pathway, PI3K/ AKT signaling pathway, and NF- $\mathrm{kB}$ signaling pathway. Molecular mechanisms of DHA on apoptosis of cancer cells still need further clarify.

\section{Additional file}

Additional file 1: Table S1. Apoptosis pathway-focused gene expression profiling of DU145 cells following DHA exposure. (DOCX $21 \mathrm{~kb}$ )

\section{Abbreviations}

AA: Arachidonic acid; DHA: Docosahexaenoic acid; EPA: Eicosapentaenoic acid; PUFA: Polyunsaturated fatty acids; RT-qPCR: Real time quantitative polymerase chain reaction 


\section{Acknowledgements}

None.

\section{Funding}

None.

\section{Availability of data and materials}

All data and material involved in this work are available.

\section{Authors' contributions}

All authors, including YS, XJ, LH, XL and QG, have contributed to study design, experimental performance, data collection, analysis and interpretation, as well as manuscript drafting and major revision. All authors read and approved the final manuscript.

\section{Competing interests}

Yanan Sun, Xiaopeng Jia, Lianguo Hou, Xing Liu and Qiang Gao declare that they have no competing interest.

\section{Consent for publication}

All authors have reviewed the final manuscript and consented for publication.

\section{Ethics approval and consent to participate} N/A

\section{Publisher's Note}

Springer Nature remains neutral with regard to jurisdictional claims in published maps and institutional affiliations.

\section{Author details}

${ }^{1}$ Department of Obstetrics and Gynecology, Bethune International Peace Hospital of the People's Liberation Army, Shijiazhuang 050082, China. 2Department of Urology, The Third Hospital of Hebei Medical University, Shijiazhuang 050051, China. ${ }^{3}$ Department of Biochemistry and Molecular Biology, Hebei Medical University, Shijiazhuang 050017, China. ${ }^{4}$ Department of Orthopaedic Trauma, Section II, The Third Hospital of Shijiazhuang City, Shijiazhuang, Hebei 050011, China. ${ }^{5}$ Department of Nutrition and Food hygiene, Hebei Medical University, Shijiazhuang 050017, China.

\section{Received: 27 September 2016 Accepted: 7 March 2017}

\section{Published online: 23 March 2017}

\section{References}

1. Ferlay J, Shin HR, Bray F, Forman D, Mathers C, Parkin DM. Estimates of worldwide burden of cancer in 2008: GLOBOCAN 2008. Int J Cancer. 2010;127:2893-917.

2. Zhang L, Wu S, Guo L-R, Zhao X-J. Diagnostic strategies and the incidence of prostate cancer: reasons for the low reported incidence of prostate cancer in China. Asian J Androl. 2009:11:9-13.

3. Center MM, Jemal A, Lortet-Tieulent J, Ward E, Ferlay J, Brawley O, Bray F. International variation in prostate cancer incidence and mortality rates. Eur Urol. 2012;61:1079-92

4. Zhao T, Liao B, Yao J, Liu J, Huang R, Shen P, Peng Z, Gui H, Chen X, Zhang $P$. Is there any prognostic impact of intraductal carcinoma of prostate in initial diagnosed aggressively metastatic prostate cancer? Prostate. 2015;75:225-32

5. Ye D-w, Li C-I, Zhou F, Yao X, Zhang S, Dai B, Zhang H, Zhu Y, Shen Y. Epidemiological trends of prostate cancer: retrospect and prospect. China Oncol. 2007;17(3):177-80.

6. Nieto M, Finn S, Loda M, Hahn WC. Prostate cancer: Re-focusing on androgen receptor signaling. Int J Biochem Cell Biol. 2007;39:1562-8.

7. Williams CD, Whitley BM, Hoyo C, Grant DJ, Iraggi JD, Newman KA, Gerber L, Taylor LA, McKeever MG, Freedland SJ. A high ratio of dietary n-6/n-3 polyunsaturated fatty acids is associated with increased risk of prostate cancer. Nutr Res. 2011:31:1-8.

8. Norrish A, Skeaff C, Arribas G, Sharpe S, Jackson R. Prostate cancer risk and consumption of fish oils: a dietary biomarker-based case-control study. $\mathrm{Br} \mathrm{J}$ Cancer. 1999;81:1238.

9. Lin P-H, Aronson W, Freedland SJ. Nutrition, dietary interventions and prostate cancer: the latest evidence. BMC Med. 2015;13:1.
10. Sijben JW, Calder PC. Differential immunomodulation with long-chain n-3 PUFA in health and chronic disease. Proc Nutr Soc. 2007:66:237-59.

11. Epstein MM, Kasperzyk JL, Mucci LA, Giovannucci E, Price A, Wolk A, Håkansson N, Fall K, Andersson S-O, Andrén O. Dietary fatty acid intake and prostate cancer survival in Örebro County, Sweden. Am J Epidemiol. 2012;176:240-52

12. Leitzmann MF, Stampfer MJ, Michaud DS, Augustsson K, Colditz GC, Willett WC, Giovannucci EL. Dietary intake of $n-3$ and $n-6$ fatty acids and the risk of prostate cancer. Am J Clin Nutr. 2004;80:204-16.

13. Liu Z, Hopkins MM, Zhang Z, Quisenberry CB, Fix LC, Galvan BM, Meier KE. Omega-3 fatty acids and other FFA4 agonists inhibit growth factor signaling in human prostate cancer cells. J Pharmacol Exp Ther. 2015;352:380.

14. Gu Z, Wu J, Wang S, Suburu J, Chen H, Thomas MJ, Shi L, Edwards IJ, Berquin IM, Chen YQ. Polyunsaturated fatty acids affect the localization and signaling of PIP3/AKT in prostate cancer cells. Carcinogenesis. 2013;34:1968-75.

15. Gu Z, Suburu J, Chen $H_{1}$ Chen YQ. Mechanisms of omega-3 polyunsaturated fatty acids in prostate cancer prevention. BioMed Res Int. 2013;2013:1-10.

16. Aronson WJ, Kobayashi N, Barnard RJ, Henning S, Huang M, Jardack PM, Liu B, Gray A, Wan J, Konijeti R. Phase II prospective randomized trial of a lowfat diet with fish oil supplementation in men undergoing radical prostatectomy. Cancer Prev Res. 2011;4:2062-71.

17. Berquin IM, Edwards IJ, Kridel SJ, Chen YQ. Polyunsaturated fatty acid metabolism in prostate cancer. Cancer Metastasis Rev. 2011;30:295-309.

18. Calviello G, Serini S, Piccioni E. n-3 polyunsaturated fatty acids and the prevention of colorectal cancer: molecular mechanisms involved. Curr Med Chem. 2007;14:3059-69.

19. Avula CR, Zaman A, Lawrence R, Fernandes $G$. Induction of apoptosis and apoptotic mediators in balb/C splenic lymphocytes by dietary $n-3$ and $n$ - 6 fatty acids. Lipids. 1999;34:921-7.

20. Serini S, Trombino S, Oliva F, Piccioni E, Monego G, Resci F, Boninsegna A, Picci N, Ranelletti FO, Calviello G. Docosahexaenoic acid induces apoptosis in lung cancer cells by increasing MKP-1 and down-regulating p-ERK1/2 and p-p38 expression. Apoptosis. 2008:13:1172-83.

21. Edwards IJ, Sun H, Hu Y, Berquin IM, O'Flaherty JT, Cline JM, Rudel LL, Chen YQ. In vivo and in vitro regulation of syndecan 1 in prostate cells by $n-3$ polyunsaturated fatty acids. J Biol Chem. 2008;283:18441-9.

22. Meng $H$, Shen $Y$, Shen J, Zhou F, Shen S, Das UN. Effect of n-3 and n- 6 unsaturated fatty acids on prostate cancer (PC-3) and prostate epithelial (RWPE-1) cells in vitro. Lipids Health Dis. 2013;12:1.

23. Heinze VM, Actis AB. Dietary conjugated linoleic acid and long-chain n-3 fatty acids in mammary and prostate cancer protection: a review. Int J Food Sci Nutr. 2012;63:66-78.

24. Schley PD, Jijon HB, Robinson LE, Field CJ. Mechanisms of omega-3 fatty acid-induced growth inhibition in MDA-MB-231 human breast cancer cells. Breast Cancer Res Treat. 2005;92:187-95.

25. Calviello G, Palozza P, Maggiano N, Piccioni E, Franceschelli P, Frattucci A, Di Nicuolo F, Bartoh GM. Cell proliferation'differentiation'and apoptosis are modified by $n-3$ polyunsaturated fatty acids in normal colonic mucosa. Lipids. 1999;34:599-604.

26. Calviello G, Resci F, Serini S, Piccioni E, Toesca A, Boninsegna A, Monego G, Ranelletti FO, Palozza P. Docosahexaenoic acid induces proteasomedependent degradation of $\beta$-catenin, down-regulation of survivin and apoptosis in human colorectal cancer cells not expressing COX-2. Carcinogenesis. 2007:28:1202-9.

27. Serini S, Piccioni E, Merendino N, Calviello G. Dietary polyunsaturated fatty acids as inducers of apoptosis: implications for cancer. Apoptosis. 2009; 14:135-52.

28. Jing K, Song K-S, Shin S, Kim N, Jeong S, Oh H-R, Park J-H, Seo K-S, Heo J-Y, Han J. Docosahexaenoic acid induces autophagy through p53/AMPK/mTOR signaling and promotes apoptosis in human cancer cells harboring wildtype p53. Autophagy. 2011;7:1348-58.

29. Shin S, Jing K, Jeong S, Kim N, Song K-S, Heo J-Y, Park J-H, Seo K-S, Han J, Park J-I: The omega-3 polyunsaturated fatty acid DHA induces simultaneous apoptosis and autophagy via mitochondrial ROS-mediated Akt-mTOR signaling in prostate cancer cells expressing mutant p53. BioMed Res Int. 2013; 2013.

30. Hu Y, Sun H, Owens RT, Gu Z, Wu J, Chen YQ, O'Flaherty JT, Edwards IJ. Syndecan-1-dependent suppression of PDK1/Akt/bad signaling by docosahexaenoic acid induces apoptosis in prostate cancer. Neoplasia. 2010;12:826-36 
31. Sorreta AG, Stafford J, Kolenic N, Stafford S, Van Horn J, Rogers KR, Burke JK, Pardini L, Pardini RS. The dietary effect of varying ratios of omega- 6 to omega-3 and a combinational study of omega-3 enriched diets with Taxotere ${ }^{\ominus}$ on hormone refractory prostate cancer cell line PC-3 growth in vivo. Cancer Res. 2006;66:914.

32. Kato T, Sorreta AG, Rivera G, Stafford J, Pardini RS. Docosahexaenoic acid is the tumor suppressing fatty acid for human colon (WiDr, COLO 205) and prostate (PC-3, LNCaP) carcinomas. Cancer Res. 2004;64:902.

33. Chung BH, Mitchell SH, Zhang J-S, Young CY. Effects of docosahexaenoic acid and eicosapentaenoic acid on androgen-mediated cell growth and gene expression in LNCaP prostate cancer cells. Carcinogenesis. 2001;22:1201-6.

34. Calviello G, Palozza P, Piccioni E, Maggiano N, Frattucci A, Franceschelli P, Bartoli GM. Dietary supplementation with eicosapentaenoic and docosahexaenoic acid inhibits growth of Morris hepatocarcinoma 3924A in rats: effects on proliferation and apoptosis. Int J Cancer. 1998;75:699-705.

35. Collett E, Davidson L, Fan Y, Lupton J, Chapkin R. Docosahexaenoic acid inhibits oncogenic Ras activation and signal transduction in colonocytes. In: FASEB J. FEDERATION AMER SOC EXP BIOL 9650 ROCKVILLE PIKE, BETHESDA, MD 20814-3998 USA; 2000: A169-A169.

36. Hong MY, Chapkin RS, Davidson LA, Turner ND, Morris JS, Carroll RJ, Lupton $J R$. Fish oil enhances targeted apoptosis during colon tumor initiation in part by downregulating BCl-2. Nutr Cancer. 2003:46:44-51.

37. du Toit-Kohn J-L, Louw L, Engelbrecht A-M. Docosahexaenoic acid induces apoptosis in colorectal carcinoma cells by modulating the PI3 kinase and p38 MAPK pathways. J Nutr Biochem. 2009:20:106-14.

38. Berquin IM, Min Y, Wu R, Wu J, Perry D, Cline JM, Thomas MJ, Thornburg T, Kulik G, Smith A. Modulation of prostate cancer genetic risk by omega-3 and omega-6 fatty acids. J Clin Invest. 2007;117:1866-75.

39. Shaikh IA, Brown I, Schofield AC, Wahle KW, Heys SD. Docosahexaenoic acid enhances the efficacy of docetaxel in prostate cancer cells by modulation of apoptosis: The role of genes associated with the NF-KB pathway. Prostate. 2008:68:1635-46.

\section{Submit your next manuscript to BioMed Central and we will help you at every step:}

- We accept pre-submission inquiries

- Our selector tool helps you to find the most relevant journal

- We provide round the clock customer support

- Convenient online submission

- Thorough peer review

- Inclusion in PubMed and all major indexing services

- Maximum visibility for your research

Submit your manuscript at www.biomedcentral.com/submit

) Biomed Central 